\title{
Viktigheten av fysisk aktivitet og trening blant eldre
}

\author{
Hilde Lohne-Seiler ${ }^{1,2}$ og Monica Klungland Torstveit ${ }^{1}$
}

1) Universitetet i Agder, Kristiansand

2) Norges Idrettshøgskole, Oslo

Korrespondanse: Hilde Lohne-Seiler, Universitetet i Agder, Fakultet for helse- og idrettsvitenskap, Service Box 422, N-4604 Kristiansand E-mail: hilde.1.seiler@uia.no Telefon: +4738141289 Telefax +4738141301

\section{SAMMENDRAG}

Regelmessig fysisk aktivitet er viktig for eldres helse. Sammenhengen mellom en fysisk aktiv livsstil og helsegevinster som forebygging av sykdom, opprettholdelse av uavhengighet og økt livskvalitet er godt dokumentert (ACSM's Position Stand 1998; Spirduso \& Cronin, 2001; Taylor et al., 2004). Hensikten med denne oversiktsartikkelen er derfor å redegjøre for viktigheten av regelmessig fysisk aktivitet og trening i aldringsprosessen, samt utdype sammenhengen mellom en fysisk aktiv livsstil og fysisk funksjon blant eldre. Basert på en nasjonal multisenterstudie (Anderssen et al., 2009), tilfredsstilte 20\% voksne og eldre (20-85 år) de nasjonale anbefalinger om 30 minutter med daglig fysisk aktivitet. Kun 12\% i den eldste aldersgruppen (80-85 år) tilfredsstilte anbefalingene. Totalt fysisk aktivitetsnivå, målt ved hjelp av akselerometer, ble redusert med økende alder, hvor de eldste (80-85 år) hadde 50\% lavere aktivitetsnivå sammenlignet med de yngste (65-69 år) (Lohne-Seiler et al., 2012). Fra 25-års alder reduseres utholdenhet og muskelstyrke med $10 \%$ per 10 år dersom individet er inaktiv (Heath et al., 1981; Wilmore, 1991). Systematisk utholdenhets- og styrketrening ser derimot ut til å redusere tapet med inntil halvparten, det vil si en reduksjon tilsvarende 5\% per 10 år hos fysisk aktive individer (Heath et al., 1981). Eldre individer ser ut til å ha de samme treningsinduserte effekter som yngre, det vil si at man får effekt av økt aktivitet uansett alder, og da også lik prosentvis fremgang (Hagberg et al., 1989). Studier har vist at det er mulig å øke maksimalt oksygenopptak og maksimal muskelstyrke med inntil 10-20\% i løpet av en 12 ukers intervensjon (Hagberg et al., 1989; Reeves et al., 2003; Lohne-Seiler et al, in press). Da muskelstyrke ser ut til å ha en sterk sammenheng med individets funksjonsevne/mobilitet, er det viktig å kunne tilrettelegge for systematisk styrketrening for eldre for på den måten å oppnå økt muskelstyrke og derigjennom økt funksjon, forebygge fall, og økt uavhengighet i hverdagen (De Vos et al., 2005). Basert på resultatene fra den nasjonale kartleggingen av fysisk aktivitetsnivå blant norske eldre, er det nå viktig å utvikle og igangsette tiltak som kan få norske eldre mer fysisk aktive. Videre forskning trengs derfor for bedre å forstå hva som karakteriserer de minst fysisk aktive eldre og de som er mest fysisk aktive. Slik kunnskap vil være til hjelp ved utvikling av hensiktsmessige fysisk aktivitetsintervensjoner tilrettelagt for denne gruppen. Et annet aspekt er å se på effekten av kostnadseffektive intervensjonsprogrammer, som bør ha som målsetting å inkludere en stor populasjon eldre til økt fysisk aktivitet. Dette vil være formålstjenlig for både individ og samfunn.

\section{Lohne-Seiler H, Torstveit MK. The importance of physical activity and training for older adults. Nor $J$} Epidemiol 2012; 22 (2): 165-174.

\section{ENGLISH SUMMARY}

Regular physical activity in older adults is critically important to ensure healthy aging. The link between physical activity and prevention of disease, maintenance of independence, and improved quality of life is supported by strong evidence (ACSM`s Position Stand 1998; Spirduso \& Cronin, 2001; Taylor et al., 2004). The purpose of this review is therefore to clarify the importance of regular physical activity and training during the aging process and in addition, present the relationship between a physical active lifestyle and physical function/mobility among elderly. Based on a national multicenter study (Anderssen et al., 2009), 20\% of the participants (20-85 år) fulfilled the current physical activity recommendations, but only $12 \%$ in the oldest age group ( $80-85$ years). Overall physical activity level, measured objectively with an accelerometer, among older adults living in Norway decreased with increasing age, and the oldest (80-85 years) displayed a 50\% lower activity level compared to the youngest (65-69 years) (Lohne-Seiler et al., 2012). From 25 years of age, endurance capacity and muscle strength decrease with $10 \%$ each decade among inactive individuals (Heath et al., 1981; Wilmore, 1991). Systematic endurance- and strength training seem to reduce the loss with $50 \%$ per decade, which conduct for a reduction similar to $5 \%$ per decade among physically active individuals (Heath et al., 1981). Elderly seem to achieve the same training induced effects as younger individuals, which means that older adults are able to get a similar improvement in percentage as the younger ones (Hagberg et al., 1989). Even in very old people, both endurance capacity and muscle strength have been shown to improve with systematic training (Seals et al., 1984). It is well documented in several studies that it is possible to increase maximum oxygen consumption and maximum muscle strength with $10-20 \%$ in older adults in an intervention period of 12 weeks (Hagberg et al., 1989; Reeves et al., 2003; Lohne-Seiler et al, in press). Loss of muscle strength may prevent older persons from performing basic functional tasks such as lift- 
ing and moving objects, rising from a chair, and walking. Muscle strength seems therefore to be of greater importance in the ability to perform activities of daily living, compared to endurance capacity (Fiatarone et al., 1990). Increase in muscle strength may lead to improvements in functional capacity and prevent falls, dependency, and disability in later life (de Vos et al., 2005). The focus has to be targeted towards both endurance training in older adults, but not least towards systematic strength training. This way the elderly will achieve a much stronger body, and therefore will be better prepared to manage the activities of daily living and become more independent. Based on the results from the national screening of physical activity level among Norwegian elderly, it is now important to develop and initiate interventions with the goal to increase the physical activity level among the older adults living in Norway. Further research is therefore needed to better understand what characterize the least physical active elderly and the ones who are most physical active. In addition, another aspect is to measure the effect of low cost intervention studies where the goal is to recruit a high number of the elderly population. This would help guide the development of needed physical activity interventions targeted at older adults.

"Man slutter ikke å leke fordi man blir gammel, men man blir gammel fordi man slutter å leke." (Huizinga, 1955).

\section{INNLEDNING}

Fysisk aktivitet er av stor betydning for aldringsprosessen og eldres helse. Sammenhengen mellom regelmessig fysisk aktivitet og forebygging av sykdom, opprettholdelse av uavhengighet og økt livskvalitet er godt dokumentert (ACSM`s Position Stand 1998; Spirduso \& Cronin, 2001; Taylor et al., 2004). Hensikten med denne oversiktsartikkelen er derfor å redegjøre for viktigheten av regelmessig fysisk aktivitet og trening $\mathrm{i}$ aldringsprosessen, samt utdype sammenhengen mellom en fysisk aktiv livsstil og fysisk funksjon blant eldre. Oversiktsartikkelen inneholder begrepsavklaringer som presenteres $i$ et eget metodekapittel, videre omtales aktivitets- og aldersrelaterte endringer, nasjonale anbefalinger for fysisk aktivitet, status på fysisk aktivitetsnivå blant eldre i Norge, samt effekt av trening tilrettelagt for eldre basert på nasjonale og internasjonale studier. Med bakgrunn i viktigheten av spesielt styrketrening for eldre, vil dette temaet omtales i eget avsnitt. En kritisk vurdering av presenterte studier belyses også. Avslutningsvis gis det forslag til videre forskning på dette forholdsvis unge forskningsfeltet.

\section{Metode}

For å kunne besvare oversiktsartikkelens hensikt er det blitt foretatt både usystematisk og systematisk søk etter relevante studier. Det ble søkt i ulike databaser, deriblant PubMed, Scopus og Norske tidsskriftartikler, hvor følgende søkeord ble benyttet: strenght training, elderly, seniors, high-intensity strength training, muscle strength, 1RM, physical function, mobility, hypertrofi and muscle adaptation. Utvelgelsen av studier var basert på følgende kriterier: kvalitet på treningsprotokoll, kontroll av treningsbelastning, antall deltakere, intervensjons- og kontrollgruppe, grad av frafall (dropout), registrering av muskelstyrke i form av 1RM, måling av kvantitative og kvalitative endinger i muskel, samt testing av fysisk funksjon/mobilitet. I tillegg ble aktuelle bøker på temaet «Eldre, aldringsprosessen og fysisk aktivitet og trening» benyttet.

\section{Beprepsavklaringer}

Biologisk alder

Defineres som prestasjonsevne eller funksjonsevne i relasjon til levetid (Lohne-Seiler \& Langhammer, 2011).

\section{Fysisk aktivitet}

Defineres som enhver kroppslig bevegelse initiert av skjelettmuskulatur som resulterer i en vesentlig økning i energiforbruket utover hvilenivå (Shephard \& Bouchard, 1994).

\section{Fysisk inaktivitet}

Defineres som et energiforbruk som nesten ikke er høyere enn den forbrenningen vi har når vi hviler (Anderssen \& Strømme, 2001).

\section{Fysisk form}

Defineres som et sett av egenskaper/faktorer (aerob, anaerob kapasitet, muskelstyrke, muskelkoordinasjon, balanse, reaksjonstid og leddbevegelighet) som man har eller erverver seg, og som er relatert til evnen til å utføre fysisk aktivitet, hvor egeninnsatsen er avgjørende for resultat (Caspersen et al., 1985).

\section{Fysisk funksjon}

Defineres i denne sammenhengen som evnen til selvstendig å kunne utføre aktiviteter relatert til fysiske krav som man blir stilt overfor i dagliglivet, både hjemme, privat og på sin arbeidsplass (Spirduso, 1995).

\section{Helserelatert form}

Defineres som en tilstand karakterisert ved: 1) overskudd i forhold til hverdagens krav der man er avhengig av fysiske egenskaper som kondisjon, muskelstyrke, bevegelighet, koordinasjon og balanse og 2) fysiologiske trekk, biokjemiske og hormonelle kvaliteter (blodsirkulasjon, membrantransport, omsetning av næringsstoffer) som er forbundet med lav risiko for utvikling av livsstilssykdommer og lidelser (SEF, 2000).

\section{Kronologisk alder}

Defineres som antall levde år og indikerer avstanden fra fødsel (Lohne-Seiler \& Langhammer, 2011).

\section{Trening}

Regelmessig gjentagelse av fysisk aktivitet over tid, som har som mål å forbedre form, prestasjon eller helse (Shephard \& Bouchard, 1994). 


\section{FYSISK AKTIVITET, FYSISK INAKTIVITET OG TRENING}

Fysisk aktivitet gir glede, avkopling, muligheter for sosialt samvær og ikke minst opplevelse av mestring. Det er vitenskapelig dokumentert at regelmessig fysisk aktivitet forebygger en rekke sykdommer og lidelser, bidrar til å opprettholde uavhengighet og forlenger levealder (ACSM`s Position Stand, 1998; Spirduso \& Cronin, 2001; Taylor et al., 2004). Disse gevinstene er mulig å oppnå helt uavhengig av alder, og gjelder så vel for fysisk aktive voksne som for aktive eldre individer. Fysisk inaktivitet er derimot en av de viktigste risikofaktorene for å utvikle helseproblemer og sykdom (Blair et al., 2012). Fysisk inaktivitet nesten dobler risikoen for tidlig død uansett årsak, utvikling av koronarsykdom, aldersdiabetes og colon cancer, samt øker risikoen for hjerneslag, beinskjørhet og brudd. Dette resulterer ofte i redusert fysisk funksjonsnivå og uførhet $\mathrm{i}$ den eldre befolkningen (ACSM`s Position Stand, 1998).

I alle aldrer er en fysisk aktiv livsstil viktig. Regelmessig moderat fysisk aktivitet kan betraktes som vedlikehold av kroppslig funksjon og er vanligvis tilstrekkelig for å opprettholde helserelatert form. Trening er på sin side en livslang prosess for å utvikle kroppen som instrument (Lohne-Seiler \& Langhammer, 2011), og krever regelmessig gjentagelse av fysisk aktivitet over tid som har som mål å forbedre form, prestasjon eller helse (Shephard \& Bouchard, 1994). Trening kan også være strategier og teknikker for å kompensere for manglende kroppslig funksjon. Med trening følger også innlæring som i sin tur stimulerer kognisjon og hukommelsesfunksjon (Lohne-Seiler \& Langhammer, 2011).

\section{AKTIVITETS- OG ALDERSRELATERTE ENDRINGER}

Den norske befolkning har i løpet av de siste 20-30 år blitt mindre fysisk aktive, noe som i hovedsak skyldes at den daglige fysiske aktiviteten er redusert blant annet på grunn av vårt industrialiserte og stadig mer teknologiske samfunn (Hjort et al., 1996). I større grad bruker man nå sammenlignet med tidligere betraktelig mer kollektivtransport, bil, PC og TV. Konsekvensene av denne utviklingen blir mer stillesittende arbeid og et inaktivt liv, og spesielt etter fylte 60 år viser nasjonale kartleggingsundersøkelser at man mosjonerer mindre (Mære et al., 1991; Anderssen et al., 2009). I takt med dette øker både den relative og absolutte populasjonen av eldre mennesker som følge av blant annet høyere levestandard og bedre helsevesen (Brock et al., 1990). Forventet levealder for norske kvinner og menn, var henholdsvis 82 år og 78 år i 2009 (Statistisk Sentralbyrå, 2009). I Norge var det per 1. januar 20094799300 innbyggere, av disse var $85 \%$ under 65 år og $15 \%$ over. I år 2060 estimeres det at andelen over 65 år vil være dobbelt så høy, og beregninger viser at kvinner som blir født i 2060, kan forvente å leve til de blir mellom
87 og 93 år, og menn til de blir mellom 83 og 88 år (Statistisk Sentralbyrå, 2009; Lohne-Seiler \& Langhammer, 2011).

Parallelt med de aktivitetsrelaterte endringer som her er skissert, oppstår det en rekke aldersrelaterte fysiologiske endringer som følge av økt kronologisk alder som igjen gir store konsekvenser på individets fysiske form. Som 25-åring har man maksimal fysisk form $(100 \%)$, som deretter reduseres for hvert år. Sammenlignet med en 25-åring vil den fysiske formen til en 65-åring ha blitt redusert til ca. $50 \%$, og til en 80 åring redusert til ca. 30\%. Parallelt med reduksjonen av fysisk form, akselererer utviklingen av alderssykdommer, da spesielt etter 65 år (Hjort, 2000) (figur 1).

Flere faktorer bestemmer et individs fysiske form, og med økende alder reduseres blant annet aerob, anaerob kapasitet, muskelstyrke, muskelkoordinasjon, balanse og leddbevegelighet, i tillegg øker reaksjonstiden (Spirduso, 1995). Disse faktorene er ikke bare avgjørende for idrettslige prestasjoner, men også svært avgjørende for evnen til å utføre dagliglivets funksjoner. Den fysiske formen blir dermed avgjørende for et individs funksjonsdyktighet og uavhengighet (Spirduso \& Cronin, 2001). Studier har vist at selv moderat trening kan forsinke den aldersbestemte reduksjon av fysisk form med 8-10 år, og på den måten vedlikeholde, eventuelt forbedre funksjonsdyktigheten. Dette kan igjen medføre at den eldre kan forbli selvhjulpen i ytterligere noen år fremover (Shephard, 1987; Spirdu-
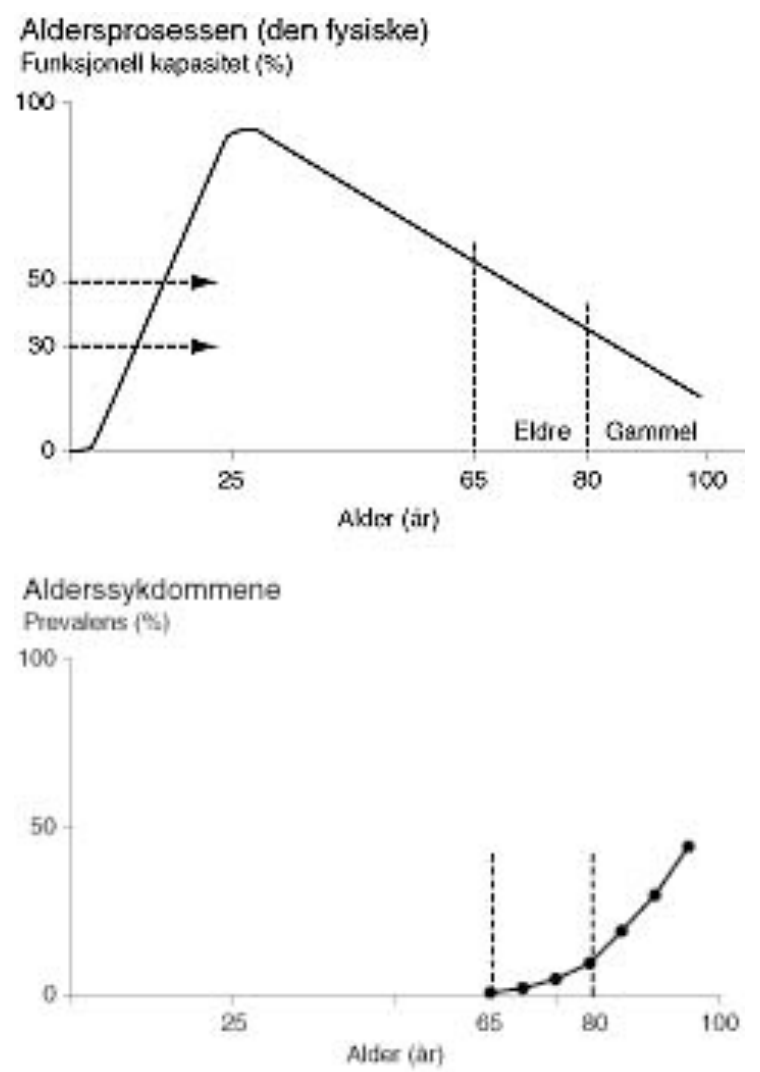

Figur 1. Den fysiske aldringsprosessen og utviklingen av alderssykdommer (Hjort, 2000, gjengitt med tillatelse). 
so \& Cronin, 2001). Kronologisk alder er en upåvirkelig faktor, mens den biologiske alder er mulig å påvirke med en aktiv livsstil. I den senere tid er flere blitt mer opptatt av individets biologiske alder, fremfor individets kronologiske alder. For å eksemplifisere dette kan en undersøkelse foretatt av Peter F. Hjort (2000) nevnes, hvor kondisjon i form av oksygenopptak hos voksne og eldre deltakere i Birkebeinerrittet på ski ble sammenlignet med en gjennomsnittsbefolkning. En 30-årig Birkebeiner hadde et oksygenopptak på ca. 70 $\mathrm{ml} / \mathrm{kg} / \mathrm{min}$ sammenlignet med ca. $45 \mathrm{ml} / \mathrm{kg} / \mathrm{min}$ hos en jevnaldret «gjennomsnittsmann». En 60-årig Birkebeiner oppnådde et oksygenopptak på over $40 \mathrm{ml} / \mathrm{kg} / \mathrm{min}$, tilsvarende det som er normalt for «gjennomsnittsmannen» på 30 år.

\section{STATUS FYSISK AKTIVITETSNIVÅ BLANT ELDRE I NORGE}

Helsedirektoratet anbefaler alle voksne og eldre å være fysisk aktive minst 30 minutter hver dag på moderat tempo, tilsvarende rask spasertur, for å oppnå helsegevinster. Ytterligere helseeffekt kan oppnås ved å øke den daglige mengden eller intensiteten utover dette (Jansson \& Anderssen, 2009).

I en landsomfattende studie fra 2004 var det kun $6 \%$ av eldre over 67 år som rapporterer at de fulgte aktivitetsanbefalingene (Waaler Loland, 2004). Basert på en nyere rapport "Fysisk aktivitet blant voksne og eldre $\mathrm{i}$ Norge“, utgitt av Helsedirektoratet i 2009 (Anderssen et al., 2009) var det kun 1 av 5 (20\%) voksne og eldre (20-85 år) som rapporterte at de var aktive i henhold til de nasjonale anbefalinger om 30 minutter med daglig fysisk aktivitet. Kun $12 \%$ i den eldste aldersgruppen (80-85 år) tilfredsstilte anbefalingene. Det var ingen vesentlige forskjeller mellom kvinners og menns aktivitetsnivå i Norge, dette gjaldt også aldersgruppen over 65 år. Totalt fysisk aktivitetsnivå, målt ved hjelp av akselerometer (objektiv målemetode), var signifikant redusert med økende alder, noe som tilsvarte en reduksjon på 5\% fra aldersgruppen 65-69 år til 70-74 år, $21 \%$ reduksjon fra $70-74$ til $75-79$ år, mens $32 \%$ reduksjon ble observert mellom aldersgruppen 75-79 til 80-85 år. Den eldste aldersgruppen (80-85 år) hadde $50 \%$ lavere totalt fysisk aktivitetsnivå sammenlignet med den yngste aldersgruppen (65-69 år). Totalt fysisk aktivitet var også assosiert med selv-rapportert helse. Selv-rapportert helse ble registrert som «meget god helse», «god helse», «verken god eller dårlig helse» og «dårlig/veldig dårlig helse». Signifikante forskjeller i totalt fysisk aktivitetsnivå ble registrert mellom de ulike selv-rapporterte helsegrupper, unntagen mellom gruppene eldre som rapporterte deres helse som «verken god eller dårlig» og «dårlig/veldig dårlig» (LohneSeiler et al., 2012).

For den eldre selv kan fysisk inaktivitet, i tillegg til helseproblemer og sykdom, føre til redusert ganghastighet og -funksjon og dermed blir det vanskeligere å komme seg ut på tur, lage mat, handle, gjøre hus- og hagearbeid, men også problemer med de mest primære gjøremål som å spise, påkledning og å gå på toalettet. Det sosiale livet blir begrenset av mindre sosial omgang, og mange opplever depresjon. Dette kan så påvirke både individets livskvalitet, selvbilde og selvtillit. I større perspektiv aner vi store samfunnsøkonomiske konsekvenser.

\section{EFFEKT AV FYSISK AKTIVITET OG TRENING}

Norge har den høyest rapporterte forekomsten av hoftebrudd i Vest-Europa (Bergland et al., 1998; Kanis et al., 2012). Dette sees ofte i sammenheng med fall. Risikofaktorer for fall er mange, og her kan nevnes: redusert gangfunksjon som ofte sees i sammenheng med svekket muskelstyrke og redusert balanse, økt reaksjonstid, redusert leddbevegelighet, inaktivitet, bor alene, medikamentbruk, økende alder og en tidligere fallhistorie (Skelton \& Todd, 2004). Problemer med å opprettholde balanse under gange viser seg å være et tydelig varsel om fall blant hjemmeboende eldre (Bergland et al., 2000). Ved å redusere risikofaktorene for fall kan trolig hyppigheten av fall reduseres.

Effekt av fysisk aktivitet og trening blant eldre har vært et forskningsfelt siden 1980-tallet internasjonalt, og så sent som fra 1990-tallet nasjonalt. Det er slått fast at eldre har de samme treningsinduserte effekter som yngre, det vil si at man får effekt av økt aktivitet uansett alder, og da også lik prosentvis fremgang (Hagberg et al., 1989). Trening kan imidlertid ikke stoppe de fysiske endringer som skjer med den aldrende kroppen, men det er mulig å bremse reduksjonen med inntil halvparten per 10 år om man sammenligner fysisk aktive eldre med inaktive (Heath et al., 1981; Hagberg et al., 1985). Fra 25-årsalderen reduseres utholdenhet (kondisjon) og muskelstyrke med ca. $10 \%$ per 10 år, om man er inaktiv (Heath et al., 1981; Wilmore, 1991). Men dersom man driver med regelmessig fysisk aktivitet $\mathrm{i}$ form av utholdenhetstrening og styrketrening, er tapet halvert til 5\% per 10 år (Heath et al., 1981). Spesielt oppløftende er det at dårlig kondisjon og muskelstyrke kan bedres også ved meget høy alder (Seals et al., 1984). I denne sammenheng er det viktig med allsidig og variert trening. Inaktive eldre som starter med systematisk utholdenhetstrening har mulighet til å øke maksimalt oksygenopptak med inntil 10-20\% i løpet av en 12-ukers treningsperiode (Hagberg et al., 1989). Det vil si at det individet har tapt av kondisjon over en 10 års periode med inaktivitet, kan gjenvinnes kun $\mathrm{i}$ løpet av 12 uker med systematisk trening. Treningsprogram med flere komponenter, som bevegelighet, balanse, gange og styrkeaktivitet ga større leddbevegelighet i hofte og økt balanse hos en gruppe eldre etter 3 måneder (Brown \& Holloszy, 1991). Annen forskning viser at kun etter 8 uker med forholdsvis stor belastning på styrketrening i en gruppe eldre med gjennomsnittsalder 90 år økte maksimal muskelstyrke med 174\% i høyre bein og 180\% i venstre bein (Fiatarone et al., 1990). Denne formidable styrkeøkningen ga også en 
overføringsverdi i form av forbedret funksjon/mobilitet (2 av 3 trengte ikke lenger støtte for å reise seg og to sluttet med stokk). Lord et al. (1996) viste også en sterk sammenheng mellom muskelstyrke i beina og ganghastighet, samt gangfunksjon. Økt muskelstyrke i beina førte til økt ganghastighet over en gitt distanse, samt forbedret gangfunksjon i form av blant annet økt skrittlengde blant en gruppe eldre kvinner i alderen 6083 år (Lord et al., 1996). Dette kan ha betydelige effekter for de eldre i dagliglivet. Et eksempel; å bevege seg over gaten "på grønn mann" krever en ganghastighet på minimum 1,2 meter per sekund (Statens vegvesen. Håndbok, 2007). En ganghastighet under dette kan gi store konsekvenser for den eldre selv.

Muskelstyrke er trolig mer avgjørende for evnen til god mobilitet/funksjon enn det utholdenhet er (Fiatarone et al., 1990), og god nevromuskulær funksjon (samspillet mellom nerve og muskel) er grunnlaget for mestring av hverdagens aktiviteter (Fiatarone et al., 1990). Med tanke på økt mobilitet/funksjon betyr dette at man ikke bare bør fokusere på bevegelse i form av utholdenhetsaktiviteter som gange, sykling og svømming, men at man også bør fokusere på styrke- og balansetrening hos eldre.

I forbindelse med gjennomføringen av studien, "Tradisjonell versus funksjonell styrketrening" (LohneSeiler et al., in press), rapporterte deltakerne følgende:

"Treningen har gitt meg overskudd. I kraftkrevende danser svinger jeg damene vesentlig lettere." "Løfter nå en bag tilsvarende $10 \mathrm{~kg}$ opp og ned fra bagasjehylle på tog og fly, noe jeg ikke klarte før. Reiser meg fortere og lettere opp fra sittestilling." "Våger mer, er ikke så redd for å ta meg mer ut i hverdagen." "Jeg føler det enklere og tryggere å gå i ulendt terreng. Jeg går lettere ut og inn i biler. Av-og påkledning av tøy går lettere. Er ikke så redd for å utsette meg for fysiske utfordringer/belastninger."

Slike selvrapporterte gevinster er det man ønsker å oppnå ved systematisk økning av muskelstyrke hos eldre individer. Man må heller ikke glemme de sosiale og psykologiske gevinster i denne sammenheng. I Aktivitetshåndboken, utgitt av Helsedirektoratet i 2009, viser de til positive sammenhenger mellom kondisjons- og styrketrening og psykologisk funksjon. Det sosiale miljøet hvor den fysiske aktiviteten finner sted har sannsynligvis en positiv virkning på hukommelse, tankeevne, initiativ, evne, humør og hukommelse (Lexell et al., 2009). Dette er for øvrig ikke godt nok dokumentert.

Siden muskelstyrke trolig er mer avgjørende for evnen til god mobilitet/funksjon blant eldre enn det utholdenhet er (Fiatarone et al., 1990), har vi valgt å utdype temaet styrketrening blant eldre i denne oversiktsartikkelen.

\section{STYRKETRENING OG ELDRE}

Styrketrening er en regelmessig og systematisk måte å trene en muskel eller muskelgruppe på, som har som målsetting å øke evnen til kraftutvikling (Gjerset et al., 1996). Muskelkraft er den kraften som produseres når muskelen trekker seg sammen. Både nervesystemets aktivering av muskelen og størrelsen på muskelen er avgjørende for kraftutvikling. Muskelstyrke er dermed bestemt ut ifra den mengde kraft som muskulaturen kan produsere gjennom et arbeid (Gjerset et al., 1996). Om man er 20-30 eller 70-80 år så er man avhengig av en viss muskelstyrke for å kunne gjennomføre aktiviteter i hverdagen. Alt fysisk arbeid krever muskelaktivitet.

Normal aldring er karakterisert av et progressivt tap av muskelstyrke, som hovedsakelig er grunnet muskelsvinn (Spirduso, 1995; Wilmore, 1991). Det vil si tap av muskelmasse, og muskelen reduseres dermed i størrelse. Allerede fra midten av 20-årene starter denne prosessen, med et tap på ca. $1 \%$ per år dersom man er lite fysisk aktiv. Aldersrelatert tap av muskelmasse har sammenheng med endringer i sentralnervesystemet, samt tap av antall muskelfibre og redusert fiberstørrelse (Lexell et al., 1988). Andre mekanismer bidrar også til muskelsvinn, som metabolske, hormonelle, ernæringsmessige og immunologiske endringer (Doherty, 2003). Det er spesielt de eksplosive og raske muskelfibrene (type II-fibre) som blir hardest rammet (Narici et al., 2004). Dette fører til et dramatisk tap av evnen til å produsere muskelkraft, man får svakere muskler, og ikke minst redusert evne til kraftutvikling under forhold med høy hastighet. Man blir både "svakere og tregere". Dette er en uheldig kombinasjon med tanke på aktiviteter som å forsere høyde hindringer, gjøre tyngre hus- og hagearbeid, hogge ved, skru opp et syltetøyglass, gå fort opp trapper, reise seg raskt opp, øke tempoet for å rekke bussen etc. Det positive er imidlertid at disse endringene som skjer som følge av kombinasjonen økt alder med fysisk inaktivitet er mulig å kunne påvirke ved hjelp av systematisk styrketrening (Morse et al., 2004).

Dersom man er i regelmessig fysisk aktivitet, og er bevisst på å belaste musklene, kan trolig det årlige tapet av muskelstyrke reduseres med inntil halvparten (fra $1 \%$ til $1 \frac{2}{2} \%$ per år). Noe reduksjon vil man uansett få som følge av alderen i seg selv, men det gjelder å være bevisst viktigheten av å påføre musklene belastning. Jo tidligere man starter, jo mindre blir det totale tapet (Spirduso, 1995).

\section{PrAKTISKE ANBEFALINGER VED STYRKE- TRENING TILRETTELAGT FOR ELDRE}

Det bør tilrettelegges for regelmessig styrketrening 2-3 ganger per uke, og med forholdsvis høy belastning på øvelsene. I Aktivitetshåndboken utgitt i 2009 anbefales det å jobbe på ca. $80 \%$ av den maksimale vekten man er i stand til å løfte. Dette gjelder også for aldersgruppen 65 år og eldre (Bahr, 2009). I tillegg anbefales det å legge inn øvelser hvor man tenker høy hastighet, dette for å påvirke de raske muskelfibrene. Belastningen må økes progressivt etter hvert som individet blir ster- 

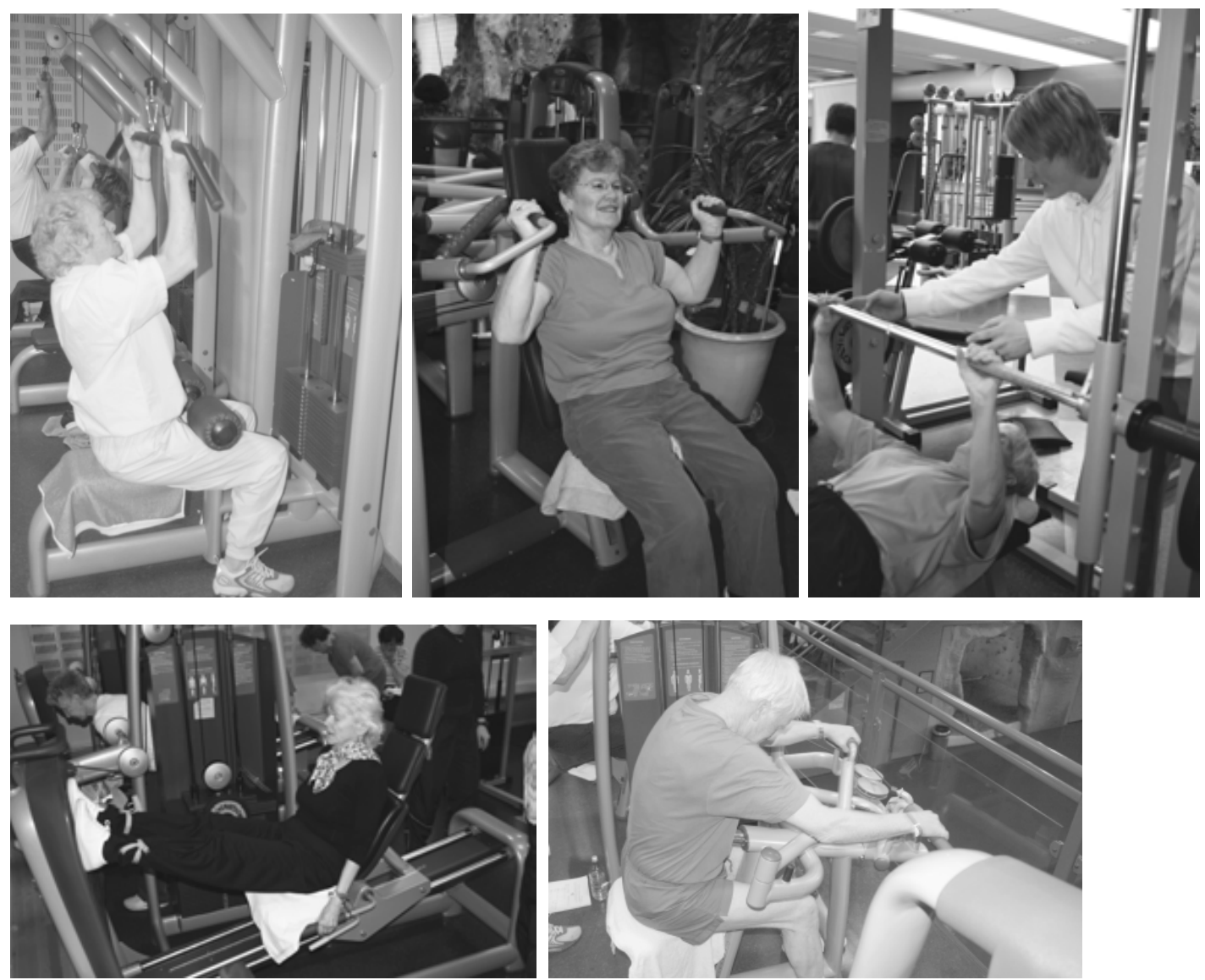

Figur 2. Styrketrening i faste apparater (Lohne-Seiler et al., in press).

kere! Det skal oppleves tungt og anstrengende. Allerede etter 8-12 uker er det mulig å øke muskelstyrken med opptil 10-20\% hos eldre utrente individer (Reeves et al., 2003; Lohne-Seiler et al., in press). Videre er en $ø$ kning av muskelens tverrsnitt (hypertrofi) på opptil $10 \%$ også dokumentert (Harridge et al., 1999; Patten \& Kamen, 2000; Reeves et al., 2003). Ved hjelp av muskelbiopsier har det også vært mulig å vise til muskelvekst av både type I-fiber (langsomme og utholdende) og type II-fiber (raske), som følge av systematisk styrketrening (Frontera et al., 1988; Häkkinen et al., 2001; Schulte \& Yarasheski, 2001). Trener man i faste apparater (se figur 2), er det enkelt å kontrollere for den belastningen man ønsker å påføre kroppen. Ved denne form for styrketrening jobber man isolert med en og en muskelgruppe. Fordelen her er at man har stor mulighet for å oppnå økt muskelmasse og muskelstyrke, så fremt belastningen er høy nok. Det er også trolig forbundet mindre risiko for skade ved denne type styrketrening.

Økt muskelstyrke har sammenheng med både hypertrofi av muskelen, og forbedring av nervesystemets aktivering av muskelen. For å oppnå den sistenevne effekten, er trolig den beste måten å trene styrke på under en situasjon hvor forholdene er ustabile, noe som medfører at man må stabilisere og justere ved hjelp av stor muskelaktivitet (integrering av flere muskelgrup- per, inkludert kjernemuskulatur). Det vil blant annet si trening med løse vekter, trening i slynger og på gymnastikkball, eller funksjonell styrketrening som for eksempel å gå/løpe opp ei trapp med sekk på ryggen, og løfte kasser opp og ned (se figur 3). I tillegg får man trolig ved denne type trening også balansestimuli og derigjennom økt balanseevne, som tidligere nevnt kan ha positiv sammenheng med fallforebygging. En studie av Cosio-Lima et al. (2003) viste at kun etter 5 uker med systematisk trening på ustabilt underlag (øvelser på gymnastikkball) blant en gruppe kvinner økte både balanse evne og EMG aktivitet målt i ryggog magemuskulatur. Disse endringene var signifikant forskjellige fra kontrollgruppen, som gjennomførte tilsvarende øvelser på gulvet, det vil si på stabilt underlag hvor kjernemuskulatur ikke ble integrert i samme grad som på ustabilt underlag.

Ved økt muskelmasse oppnås også andre gevinster som økt stoffskifte, noe som er gunstig for vektregulering. Her bør det nevnes at kombinasjonen utholdenhetstrening og styrketrening, i tillegg til sunne kostholdsvaner gir den beste effekten. For å få optimalt utbytte av styrketreningen, er det også viktig å ta hensyn til hva man spiser. For den eldre mann og kvinne er et normalt og fornuftig kosthold å foretrekke, hvor proteinbehovet blir dekket. I følge de nasjonale anbefalinger bør kosten inneholde 30\% fett, 50-60\% karbo- 

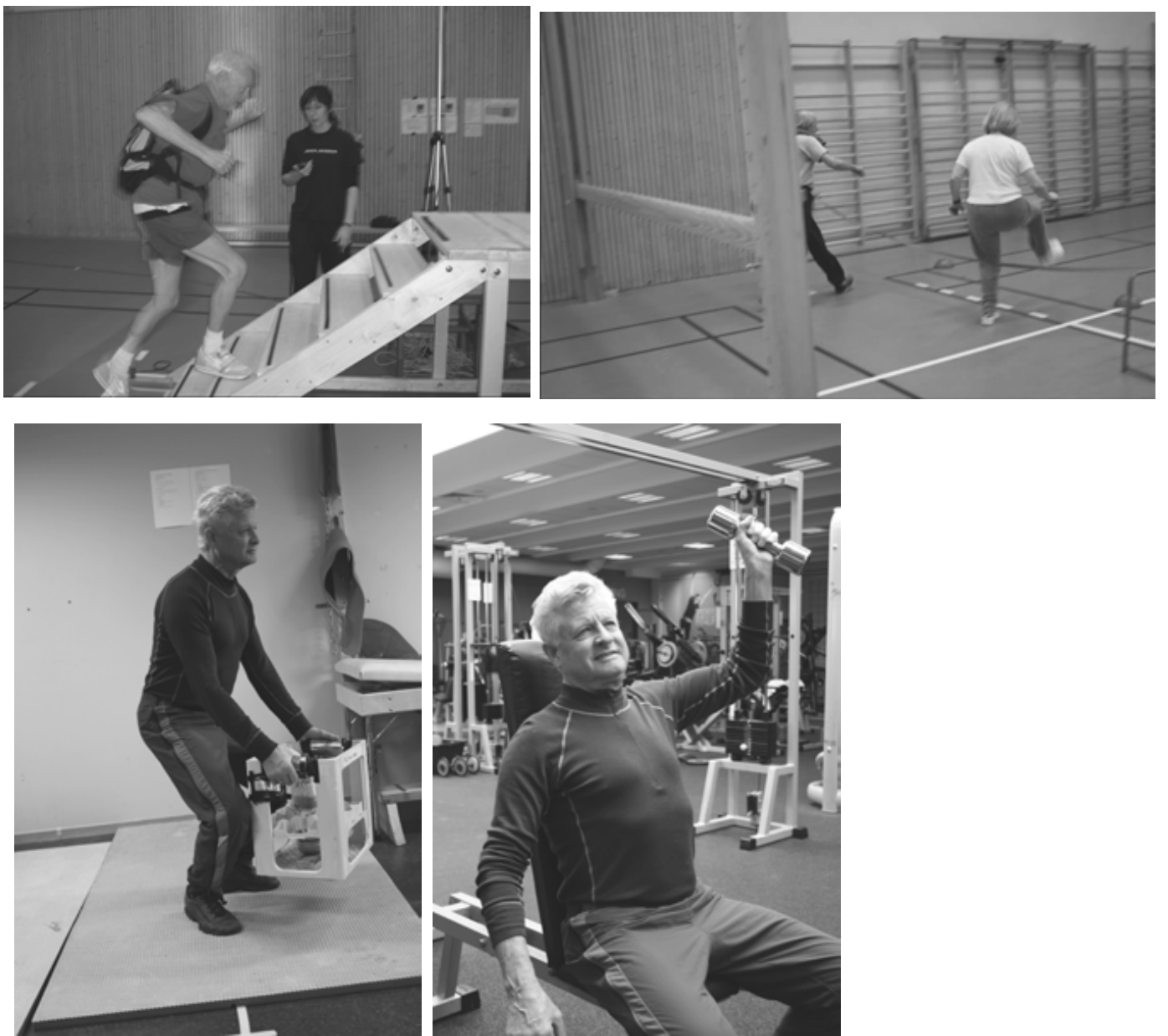

Figur 3. Funksjonell styrketrening (Lohne-Seiler et al., in press).

hydrat, og 10-20\% protein (Helsedirektoratet, 2012). For eldre som trener regelmessig er det også av betydning å spise regelmessige måltider (helst hver 3.-4. time), samt ha fokus på å spise og drikke nok både før og etter trening.

Det viktigste argumentet for å trene muskelstyrke når man blir eldre, er og bør være at individet får en sterkere kropp, en kropp som tåler mer og blir i bedre stand til å håndtere de fysiske belastningene individet møter i hverdagen. På den måten vedlikeholdes, eventuelt forbedres fysisk funksjon og grad av mobilitet, som igjen fører til at det enkelte individ kan være selvhjulpen i ytterligere mange år, uten større hjelp fra det offentlige helsevesen. Det individet har tapt av muskelstyrke på 10 år, kan gjenvinnes kun i løpet av 12 uker med systematisk og riktig styrketrening. Men trening er ferskvare og må derfor vedlikeholdes for at effekten skal opprettholdes.

\section{EN KRITISK VURDERING AV PRESENTERTE STUDIER}

En kritisk vurdering skisseres nå i forhold til de intervensjonsstudier det refereres til i denne oversiktsartikkelen, og er basert på følgende kriterier: kvalitet på treningsprotokoll, kontroll av treningsbelastning, antall deltakere, kjønnsfordeling, intervensjons- og kontrollgruppe, drop-out, registrering av muskelstyrke i form av 1RM, måling av kvantitative og kvalitative endringer i muskel, samt testing av fysisk funksjon/mobilitet. Mange av de presenterte treningsstudier benyttet seg av systematiske treningsprotokoller, hvor de fulgte standard rehabiliteringsprinsipper ved tilrettelegging av styrketrening for eldre individer (Frontera et al., 1988; Fiatarone et al., 1990; Harridge et al., 1999; Patten \& Kamen, 2000; Häkkinen et al., 2001; Schulte \& Yarasheski; Reeves et al., 2003; Lohne-Seiler et al., in press). For øvrig ble treningsbelastningen (tilsvarende $80 \%$ 1RM) i disse studiene ukentlig justert etter hvert som 1RM økte. Lengden på intervensjonen varierte derimot, alt fra 8 uker (Fiatarone et al., 1990), 12-14 uker (Brown \& Holloszy, 1991; Reeves et al., 2003; Lohne-Seiler et al., in press), til 22 uker (Lord et al., 1996). Flere av studiene (Frontera et al., 1988; Fiatarone et al., 1990; Reeves et al., 2003) har også et lavt antall deltakere inkludert, samt en skjevfordeling mellom menn og kvinner (Fiatarone et al., 1990), noe som kan føre til redusert generalisertbarhet av resultatene. I enkelte studier (Fiatarone et al., 1990; Frontera et al., 1988) rapporteres effekter av trening kun basert på 
inklusjon av en intervensjonsgruppe, uten å inkludere en kontrollgruppe. Studier rapporterer også om dropout, og da spesielt knyttet til kontrollgruppen (LohneSeiler et al., in press). En styrke ved flere av studiene (Fiatarone et al., 1990; Lord et al., 1996; Lohne-Seiler et al., in press) er at de i tillegg til å måle styrkeforandringer i muskel i form av 1RM, også ser på overføringsverdien av disse endringene til funksjon/mobilitet, som blant annet ble registrert som gangobservasjoner, med og uten støtte under forflytning, «reise seg opp fra stol manøver» og løftekapasitet. Hypertrofi av muskelmasse ble i flere av de presenterte studier registrert ved hjelp av computerbasert tomografi (CT scan) og ultralydmålinger (Fiatarone et al., 1990; Frontera et al., 1988; Harridge et al., 1999; Patten \& Kamen, 2000; Reeves et al., 2003). Muskelbiopsier ble også foretatt for å kunne identifisere endringer på muskelfibernivå, det vil si forholdet mellom type I og II fiber, i flere av de refererte studier (Frontera et al., 1988; Häkkinen et al., 2001; Schulte \& Yarasheski, 2001).

\section{OPPSUMMERING}

Fysisk aktivitet er uten tvil positivt for de eldres helse og fysiske funksjon. Regelmessig fysisk aktivitet med moderat intensitet og med en varighet på minst 30 minutter per dag, vil kunne redusere sykelighet og dødelighet, samt medvirke til å bedre evnen til å utføre dagliglivets oppgaver. Per i dag er for få eldre fysisk aktive ifølge anbefalingene. Det er av stor betydning for samfunnet generelt og for det enkelte individ spesielt å øke aktivitetsnivået. All aktivitet er bedre enn ingen aktivitet og det er aldri for sent å begynne. Positive effekter er vist også blant aktive eldre med høy alder. Det er imidlertid viktig ikke kun å fokusere på utholdenhetsaktiviteter, men også inkludere balanseøvelser, og ikke minst styrketrening for denne aldersgruppen. Ved å drive regelmessig styrketrening vil individet kunne oppnå en sterkere kropp som er bedre $\mathrm{i}$ stand til å håndtere aktiviteter i hverdagen. Helsepersonell og andre i kontakt med eldre bør motivere denne aldersgruppen for en fysisk aktiv hverdag. Gevinstene er store. Nå må det satses på de eldre!

\section{FORSLAG TIL VIDERE FORSKNING}

Basert på resultatene fra den nasjonale kartleggingen av fysisk aktivitetsnivå blant norske eldre individer, er det nå viktig å utvikle og igangsette tiltak/intervensjoner som kan få eldre $\mathrm{i}$ økt fysisk aktivitet. Videre forskning trengs derfor for bedre å forstå hva som karakteriserer de minst fysisk aktive eldre og de som er mest fysisk aktive. Slik kunnskap vil være til stor hjelp ved utvikling av hensiktsmessige fysisk aktivitets intervensjoner tilrettelagt for denne gruppen. Et annet interessant aspekt er å se på effekten av kostnadseffektive intervensjonsprogrammer, som bør ha som målsetting å inkludere en stor populasjon eldre til økt fysisk aktivitet. Dette vil være formålstjenlig for både individ og samfunn.

\section{REFERANSER}

American College of Sports Medicine (ACSM) Position Stand. Exercise and physical activity of older adults. Med Sci Sports Exerc 1998; 30: 992-1008.

Anderssen SA, Strømme S. Fysisk aktivitet og helse - anbefalinger. Tidsskr Nor Laggeforen 2001; 121: $2037-41$.

Anderssen SA, Hansen BH, Kolle E, Steene-Johannessen J, Børsheim E, Holme I, Kan-1-gruppen. Fysisk aktivitet blant voksne og eldre i Norge. Resultater fra en kartlegging i 2008 og 2009. Oslo: Helsedirektoratet, 2009. Rapport 15-1754.

Bahr R (red.). Aktivitetshåndboken: fysisk aktivitet i forebygging og behandling. Oslo: Helsedirektoratet, 2009.

Bergland A, Pettersen AM, Laake K. Falls reported among elderly Norwegians living at home. Physiother Res Int 1998; 3: 164-174.

Bergland A, Pettersen AM, Laake K. Functional status among elderly Norwegians fallers living at home. Physiother Res Int 2000; 5: 33-45.

Blair SN, Sallis RE, Hutber A, Archer E. Exercise therapy - the public health message. Scand J Med Sci Sports 2012; 22: e24-e28.

Brock DB, Guralnik JM, Brody JA. Demography and epidemiology of aging in US. I: Sneider EL, Rowe JW (red.). Handbook of the biology of aging. San Diego: Academic Press, 1990: 3-23.

Brown M, Holloszy JO. Effects of a low intensity exercise program on selected physical performance characteristics of 60 to 70 year olds. Aging 1991; 3: 129-139.

Caspersen CJ, Powell KE, Christensen GM. Physical activity, exercise and physical fitness: definitions and distinctions for health-related research. Public Health Rep 1985; 2: 126-131.

Cosio-Lima LM, Reynolds KL, Winter C, Paolone V, Jones MT. Effects of physioball and conventional floor exercises on early phase adaptations in back and abdominal core stability and balance in women. $J$ Strength Cond Res 2003; 17 (4): 721-725.

de Vos NJ, Singh NA, Ross DA, Stavrinos TM, Orr R, Fiatarone Singh MA. Optimal load for increasing muscle power during explosive resistance training in older adults. J Gerontol A Biol Sci Med Sci 2005; 60: 638-647. 
Doherty TJ. Aging and sarcopenia. J Appl Physiol 2003; 95: 1717-1729.

Fiatarone MA, Marks EC, Ryan N, Meredith CN, Lipsitz L, Evans WJ. High intensity strength training in nonagenarians: effects on skeletal muscle. JAMA 1990; 263: 3029-3034.

Frontera WR, Meredith CN, O'Reilly KP, Knuttgen HG, Evans WJ. Strength conditioning in older men: skeletal muscle hypertrophy and improved function. J Appl Physiol 1988; 64: 1038-1044.

Gjerset A, Haugen K, Holmstad P. Treningslaere. Oslo: Universitetsforlaget, 1996.

Hagberg JM, Allen WK, Seals DR, Hurley BF, Ehsani AA, Holloszy JO. A hemodynamic comparison of young and older endurance athletes during exercise. J Appl Physiol 1985; 58: 2041-2046.

Hagberg JM, James E, Graves ML, Limacher DR, Woods SH, Leggett C, Cononie JJG, Pollock ML. Cardiovascular responses of 70-to-79-yr-old men and women to exercise training. J Appl Physiol 1989; 66: 2589-94.

Harridge SD, Kryger A, Stensgaard A. Knee extensor strenght, activation, and size in very elderly people following strength training. Muscle Nerve 1999; 22: 831-839.

Häkkinen K, Kraemer WJ, Newton RU, Alen M. Changes in electromyographic activity, muscle fibre and force production characteristics during heavy resistance/power strength training in middle-aged and older men and women. Acta Physiol Scand 2001; 171: 51-62.

Heath GW, Hagberg JM, Ehsani AA, Holloszy JO. A physiological comparison of young and older endurance athletes. J Appl Physiol 1981; 51: 634-640.

Helsedirektoratet. Kosthåndboken: Veileder i ernceringsarbeid i helse- og omsorgstjenesten. Oslo, 2012.

Hjort PF, Waaler HT, Tverdal A, Graff-Iversen S, Trygg K. Mosjonerer folk mindre enn de tror? Tidsskr Nor Lageforen 1996; 116: 3023-3024.

Hjort PF. Fysisk aktivitet og eldres helse - gå på. Tidsskr Nor Lageforen 2000; 120: 2915-2918.

Huizinga J. Homo Ludens. USA: Roy Publishers, 1955.

Jansson E, Anderssen SA. Generelle anbefalinger om fysisk aktivitet. I: Bahr R, red. Aktivitetshåndboken: fysisk aktivitet i forebygging og behandling. Oslo: Helsedirektoratet; 2009: 37-44.

Kanis JA, Odèn A, McCloskey EV, Johansson H, Wahl DA, Cooper C. A systematic review of hip fracture incidence and probability of fracture worldwide. Osteoporos Int 2012; 23: 2239-2256.

Lexell J, Taylor CC, Sjostrom M. What is the cause of aging atrophy? J Neurol Sci 1988; 84: 275-294.

Lexell J, Frändin K, Helbostad JL. Fysisk aktivitet for eldre. I: Bahr R, red. Aktivitetshåndboken: fysisk aktivitet $i$ forebygging og behandling. Oslo: Helsedirektoratet; 2009: 62-71.

Lohne-Seiler H, Langhammer B. Fysisk aktivitet og trening for eldre. Betydningen for fysisk kapasitet og funksjon. Kristiansand: Høgskoleforlaget, 2011: 1-172.

Lohne-Seiler H, Torstveit MK, Anderssen SA. Traditional versus functional strength training. Effects on muscular strength and power among elderly. J Aging Phys Act, In press.

Lohne-Seiler H, Hansen BH, Kolle E, Anderssen SA. Accelerometer-determined physical activity and its association with self-reported health in a population of older adults (65-85 y). 17th Annual Congress of ECSS (European College of Sports Medicine) July 2012, Bruges, Belgium.

Lord SR, Lloyd DG, Nirui M, Raymond J, Williams P, Stewart RA. The effect of exercise on gait patterns in older women. J Gerontol A Biol Sci Med Sci 1996; 51: 64-70.

Morse C, Thom JM, Birch K, Davis M, Fox KR, Narici MV. Reduced plantar flexor specific torque in the elderly is associated with lower activation capacity. Eur J Appl Physiol 2004; 92: 219-226.

Mære Å, Bjørndal A, Holmen J, Midthjell K, Kjærgaard P. Mosjonsvaner hos vaksne i Nord-Trøndelag. Tidsskr Nor Lageforen 1991; 111: 3697-3699.

Narici MV, Reeves ND, Morse CI, Maganaris CN. Muscular adaptations to resistance exercise in elderly. $J$ Int Musc Neurol 2004; 4: 161-164.

Patten C, Kamen G. Adaptations in motor unit discharge activity with force control training in young and older human adults. Eur J Appl Physiol 2000; 83: 128-143.

Reeves N, Maganaris CN, Narici MV. Effects of strength training on human patella tendon mechanical properties of older individuals. J Physiol 2003; 548: 971-981.

Schulte JN, Yarasheski KE. Effects of resistance training of the rate of muscle protein synthesis in frail elderly people. Int J Sport Nutr Exerc Metab 2001; 11: 111-118.

Seals DR, Hagberg JM, Hurley BF, Ehsani AA, Holloszy JO. Endurance exercise training in older men and women: cardiocascular respons to exercise. J Appl Physiol 1984; 57: 1024-1029.

Shephard RJ. Physical activity and aging. London: Croom Helm, 1987.

Shephard RJ, Bouchard C. Principal components of fitness: relationship to physical activity and lifestyle. Can J Appl Physiol 1994; 19(2): 200-214. 
Skelton D, Todd C. What are the main risk factors for falls amongst older people and what are the most effective interventions to prevent these falls? HEN synthesis report 2004, 1-28.

Spirduso W. Physical dimensions of aging. Champaigne, USA: Human Kinetics, 1995.

Spirduso WW, Cronin DL. Exercise dose-response effects on quality of life and independent living in older adults. Med Sci Sports Exerc 2001; 33 (6 Suppl.): 598-608.

Statens Råd for Ernæring og Fysisk Aktivitet (SEF). Fysisk aktivitet og helse. Anbefalinger. Rapport nr. 2. Oslo: Helsedirektoratet, 2000.

Statens vegvesen. Håndbok 141. Trafikksignalanlegg. Oslo: Vegdirektoratet, Veg- og trafikkavdelingen, 2007.

Statistisk Sentralbyrå. Befolkningsstatistikk. Tilgjengelig fra http://www.ssb.no/befolkning/.

Taylor AH, Cable NT, Faulkner G, Hillsdon M, Narici M, Van Der Bij AK. Physical activity and older adults: a review of health benefits and the effectiveness of interventions. J Sports Sci 2004; 22 (8): 703-725.

Waaler Loland N. Exercise, health and aging. J Aging Phys Act 2004; 12: 170-184.

Wilmore JH. The aging of bone and muscle. Clin J Sport Med 1991; 10: 231-244. 